\title{
Hybrid Multilevel Inverter using ISPWM Technique for Fuel Cell Applications
}

\author{
R.Seyezhai \\ Assistant Professor \\ Department of EEE \\ SSN College of Engineering \\ Chennai, India
}

\author{
Dr.B.L. Mathur \\ Professor \\ Department of EEE \\ SSN College of Engineering \\ Chennai, India
}

\begin{abstract}
Fuel cells have been considered as the primary energy source for the distributed power generation as they are highly efficient, modular and clean. The main drawback is that the dc voltage generated by a single fuel cell varies from $0.7 \mathrm{~V}$ to $1 \mathrm{~V}$. Due to the low input voltage in fuel cells, a suitable power conditioner is required to interface to the utility grid or local loads. To meet this requirement, this paper presents the design, development and performance of a hybrid cascaded multilevel inverter. The advantage of the proposed topology is that the modulation, control and protection requirements of each bridge are modular and it requires only a single dc source in each phase leg. A twolevel H-bridge inverter using variable frequency inverted sine wave carrier modulation technique has been studied for total harmonic distortion (THD) and switching losses for fuel cell applications. A detailed study of the technique was carried out through MATLAB/SIMULINK for switching losses and THD. The results were verified experimentally. It was noticed that the proposed modulation strategy results in lower switching losses for a chosen THD as compared to the conventional strategies.
\end{abstract}

\section{General Terms}

Design, Verification

\section{Keywords}

Hybrid Multilevel Inverter, Fuel Cell, Variable frequency, ISPWM, PCS

\section{INTRODUCTION}

Multilevel inverter strategy is a practical solution for reducing harmonics. Various topologies have been reported in the literature.The cascaded multilevel inverter with separate dc sources can fit many of the needs of all electric vehicles because it can use on board batteries or fuel cells to generate a nearly sinusoidal voltage waveform to drive the main vehicle traction motor. Normally, each phase of a cascaded multilevel inverter requires " $n$ " dc sources for $2 n+1$ level. For many applications, multiple dc sources are required demanding long cables and this could lead to voltage unbalance among the dc sources. With an aim to reduce the number of dc sources required for the cascaded multilevel inverter for distributed power generation, this paper focuses on a hybrid cascade MLI(HCMLI) that uses only one dc source in each phase while the other dc source is replaced by a capacitor to generate seven level equal step multilevel output [1]. This structure is favourable for high power applications since it provides higher voltage at higher modulation frequencies (where they are needed) with a low switching (carrier) frequency. It means low switching loss for the same total harmonic distortion (THD) .It also improves the reliability by reducing the number of dc sources.

Performance of the multilevel inverter (such as switching loss and THD) for the fuel cell PCS is mainly decided by the modulation strategies. For the cascaded multilevel inverter there are several well known sinusoidal pulse width modulation strategies [2].Compared to the conventional triangular carrier based PWM, the inverted sine carrier PWM has a better spectral quality and a higher fundamental output voltage without any pulse dropping. However, the fixed frequency carrier (inverted sine or triangle) based PWM affects the switch utilization in multilevel inverters .In order to balance the switching duty among the various levels in inverters, a variable frequency carrier based PWM has been suggested.

This paper however, presents a novel variable frequency inverted rectified sine modulation technique (VFISPWM) for a single dc source seven-level inverter. This novel method combines the advantage of inverted sine and variable frequency carrier signals. The VFISPWM provides an enhanced fundamental voltage, lower total harmonic distortion (THD) and minimizes the switch utilization among the various levels in inverters. In this method the control signals have been generated by comparing sinusoidal reference signal with a high frequency inverted sine carrier. The carrier frequencies are so selected that the number of switching in each band are equal. The proposed modulation technique maximizes the output voltage and gives a low THD of 5.92\%. A comparative evaluation between the VFISPWM and the conventional Phase Disposition pulse width modulation (PDPWM) is also presented in terms of output voltage quality, power circuitry complexity, total harmonic distortion (THD), $\mathrm{DF}_{1}, \mathrm{DF}_{2}$ and implementation cost .Both the HCMLI circuit topology and its new control scheme are described in detail and their performance is verified based on simulation and experimental results.

\section{HYBRID CASCADED SEVEN-LEVEL SINGLE SOURCE INVERTER}

A comparative study of different topologies of MLI for producing the same seven-level output is available in the literature. The topology presented in this paper employs a single dc source (fuel cell) per phase to generate an equal step seven level output. The proposed inverter consists of two H-bridges per phase as shown in Figure.1. The main $\mathrm{H}$ - bridge $\left(\mathrm{H}_{1}\right)$ is connected to a dc source (fuel cell) of value $\mathrm{V}_{\mathrm{dc}}$ and the second bridge $\left(\mathrm{H}_{2}\right)$ is connected to a capacitor whose value is maintained at $0.5 \mathrm{~V}_{\mathrm{dc}}$. By appropriately opening and closing the switches of $\mathrm{H}_{1}$, the output voltage $\mathrm{V}_{1}$ can be made equal to $-\mathrm{V}_{\mathrm{dc}}, 0$, or $+\mathrm{V}_{\mathrm{dc}}$ similarly the output voltage of $\mathrm{H}_{2}$ can be made equal to $-0.5 \mathrm{~V}_{\mathrm{dc}}$, 0 , or $0.5 \mathrm{~V}_{\mathrm{dc}}$ and the cascaded output is shown in Figure.2. Therefore, the output voltage of the converter can have seven possible values $0,0.5 \mathrm{~V}_{\mathrm{dc}}, \mathrm{V}_{\mathrm{dc}}, 1.5 \mathrm{Vdc},-0.5 \mathrm{~V}_{\mathrm{dc}},-\mathrm{V}_{\mathrm{dc}}$ and $-1.5 \mathrm{~V}_{\mathrm{dc}}$. The capacitor voltage is sensed and fed to an op-amp comparator. The comparator output is given to the FPGA processor to regulate the capacitor voltage. The advantages of this topology are : 
- $\quad$ Reduced number of DC sources.

- Higher speed capability

- Low output switching frequency

- Low switching loss

- High conversion efficiency

The switching sequence for the hybrid MLI is shown in Table1.



Figure.1 Single-Phase Hybrid Cascaded Multilevel Inverter
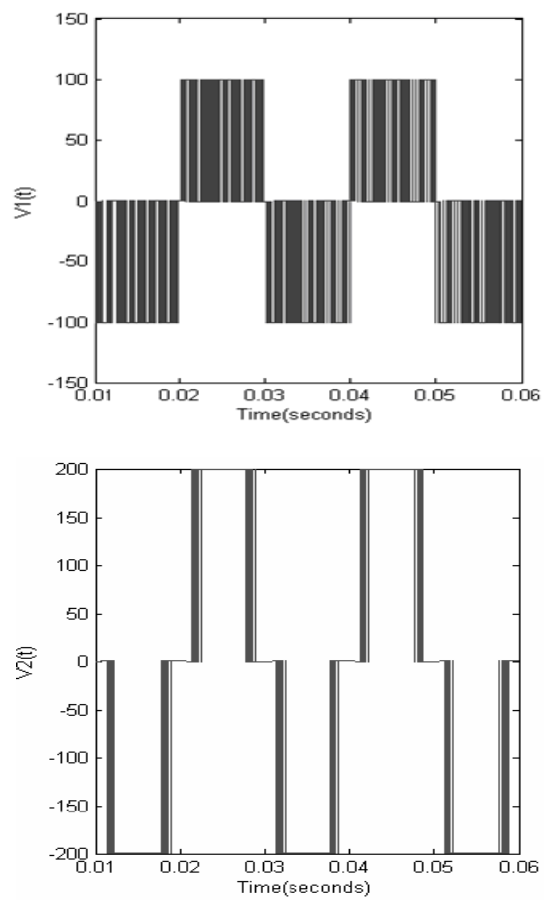



Figure.2 Output Voltage Waveform of Hybrid Cascaded Seven Level Inverter

Table 1: Switching States of Hybrid MLI

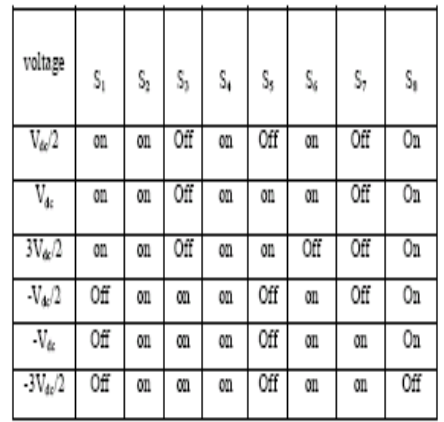

\section{PROPOSED VARIABLE FREQUENCY INVERTED SINE PWM TECHNIQUE (VFISPWM)}

For the hybrid multilevel inverter several sinusoidal PWM techniques have been developed [2,3].The most popular and simple switching scheme for multilevel inverter is the multicarrier PWM technique (MCPWM).The proposed PWM strategy replaces the conventional fixed frequency carrier waveform [6,7] by variable frequency inverted sine wave. The inverted sine PWM has a better spectral quality and a higher fundamental voltage compared to the triangular based PWM.But the main drawback is the marginal boost in the magnitude of lower order harmonics and unbalanced switch utilization. This is overcome by employing variable frequency inverted sine carrier signals. In order to balance the number of active switching among the levels is to vary the carrier frequency based on the slope of the modulating wave in each band. The frequency ratio for each band should be set properly for balancing the switching action for all levels. The reference carrier frequency was chosen as $3950 \mathrm{~Hz}$ as switching losses and THD both are low as shown in Figure.3. 


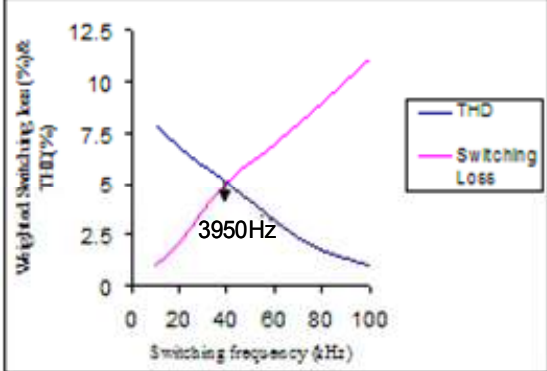

Figure.3 Reference Switching Frequency vs. THD of The conventional PDPWM technique

With the carrier reference frequency of $3950 \mathrm{~Hz}$ applied to the band-1, the new frequencies for bands 2 and 3 are assigned proportional to their respective slopes.

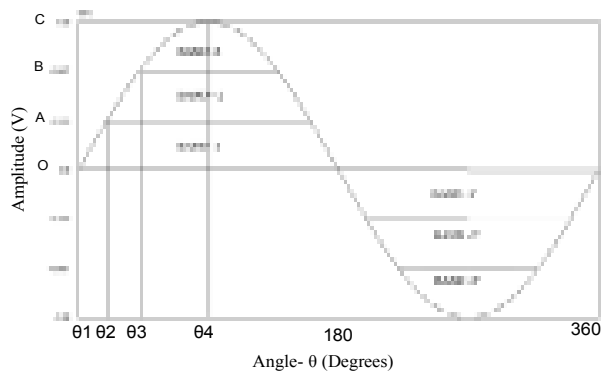

Figure.4 Reference modulating wave - Three bands for different carrier frequencies

In Figure 4, the modulating wave is defined as

$$
\mathrm{V}(\mathrm{t})=\operatorname{Sin} \theta
$$

The calculation of the slope values for the three bands is shown below:

$$
\begin{aligned}
& \theta_{1}=\operatorname{Sin}^{1} 0=0 \text { radians } \\
& \theta_{2}=\operatorname{Sin}^{-1}(1 / 3)=0.339 \text { radians }
\end{aligned}
$$

$$
\begin{aligned}
& \theta_{3}=\operatorname{Sin}^{-1}(2 / 3)=0.728 \text { radians } \\
& \theta_{4}=\operatorname{Sin}^{-1}(1)=1.5707 \text { radians }
\end{aligned}
$$

Using the slope values of the carrier band, the new frequencies are calculated as shown in table 2 and the carrier waveforms are shown in the Figure.5.

Table 2: Slope Calculation for the carrier bands, Frequency and Switching actions $\mathbf{N}_{\mathrm{sw}}$ for the Proposed VFISPWM

\begin{tabular}{|l|c|c|c|}
\hline $\begin{array}{l}\text { Carrier } \\
\text { Band }\end{array}$ & $\begin{array}{l}\text { Slope of } \\
\text { the bands }\end{array}$ & $\begin{array}{l}\mathrm{N}_{\mathrm{sw}} \text { (per } \\
\text { cycle) }\end{array}$ & $\begin{array}{l}\text { Frequency } \\
(\mathrm{Hz})\end{array}$ \\
\hline Band 1 $\mathrm{C}_{1}$ & 1.00 & 8 & 3950 \\
\hline Band 2 $\mathrm{C}_{2}$ & 0.8716 & 8 & 3443 \\
\hline Band 3 $\mathrm{C}_{3}$ & 0.4040 & 8 & 1596 \\
& & & \\
\hline
\end{tabular}

The number of switching actions (8) is balanced for all the switches in the proposed PWM technique as shown in table III:

Table 3 : Switching Actions for the PWM Techniques

\begin{tabular}{|l|l|l|}
\hline Parameter & $\begin{array}{l}\text { Proposed } \\
\text { VFISPWM }\end{array}$ & $\begin{array}{l}\text { Conventional } \\
\text { PWM }\end{array}$ \\
\hline $\mathrm{N}_{\mathrm{sw}}$ & $\mathbf{4 8}$ & 72 \\
\hline THD & $\mathbf{5 . 9 2 \%}$ & $7.98 \%$ \\
& & \\
\hline
\end{tabular}

Hence, with reduced number of active device switching per cycle, switching losses can be reduced compared to the

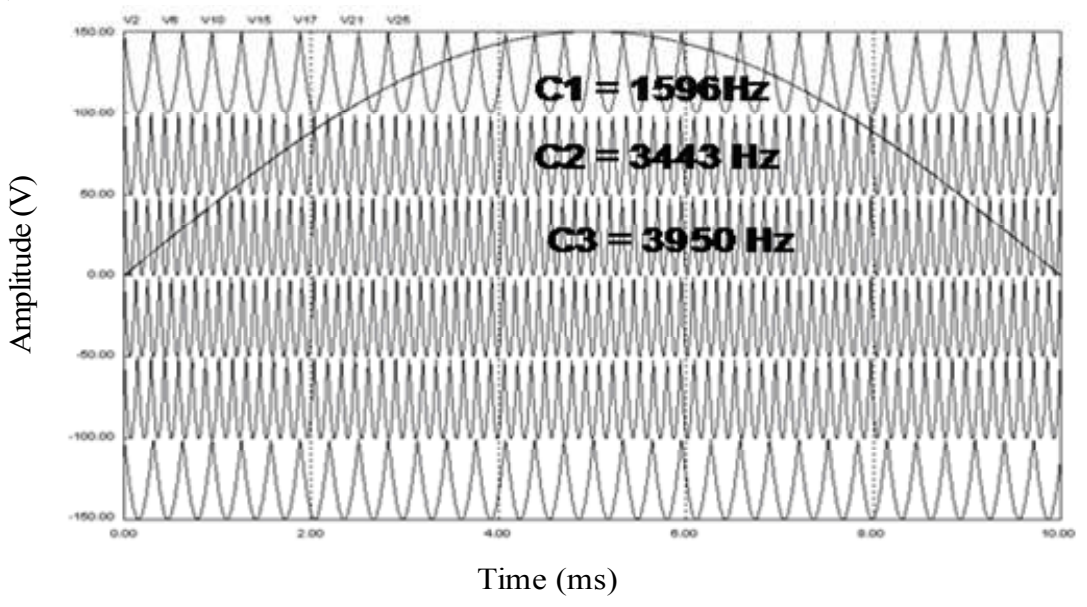

Figure.5 Carrier and reference waveforms for the proposed variable frequency ISPWM 
conventional ISPWM techniques [4,5].The carrier waveforms for the proposed VFISPWM are shown in the Figure.5. $\left(\mathrm{C}_{1}, \quad \mathrm{C} 2\right.$ and $\mathrm{C}_{3}$ refer to the carrier waveforms).Figure.6. shows the block diagram of gating pattern for the hybrid multilevel inverter. The comparator output is given to a 3-input XOR gate that generates gating signals to the corresponding switches.

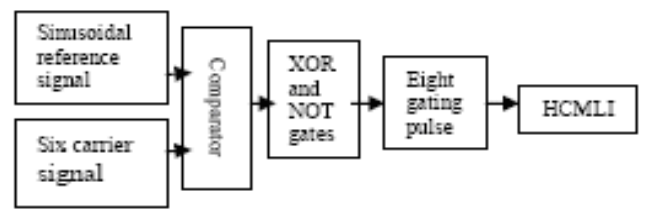

Figure.6 Block Diagram of Pulse Generation for VFISPWM

\section{CHARACTERISTICS OF A PEM FUEL CELL}

Proton exchange membrane (PEM) fuel cell is one of the promising technologies for alternative source of power generation in future. Fuel cells are a source of DC voltage but for many applications AC supply is required and hence inverter circuit fed by a fuel cell is important. The proton exchange membrane (PEM) fuel cell is very simple and uses a polymer (membrane) as the solid electrolyte and a platinum catalyst. The hydrogen from a pressurized cylinder enters the anode of the fuel cell and the oxygen (from air) enters the cathode. Protons and electrons are separated from hydrogen on the anode side. The electrical characteristics of the fuel cell output can be represented by current density versus voltage curve as shown in Figure.7.The voltage at lower current density drops significantly at higher load current and maximum power occurs in the ohmic region. Hence, ohmic region is used as a voltage window for the power conditioner unit input. Since the output voltage generated by each fuel cell is relatively low at full output current, they are stacked in series to produce the required voltage level. In this paper, an electrochemical model is proposed to simulate a PEM fuel cell system which accounts for the effects of different dynamic conditions in load current, pressure of input reactant gases, and fuel cell operating temperature. Many models have been proposed for simulation of the fuel cell in the literature [11] but the model proposed in this paper includes the transient dynamics of fuel cell which will be suited for power generation applications.



Figure .7 Ideal VI Characteristics of a Single PEM Fuel Cell
The output voltage of a single cell can be defined as

$$
\mathrm{V}_{\text {fc }}=\mathrm{E}_{\text {nerst }}-\mathrm{V}_{\text {act }}-\mathrm{V}_{\text {ohm }}-\mathrm{V}_{\text {conc }}
$$

In (6), $E_{\text {Nerst }}$ represents the reversible voltage; $V_{\text {act }}$ is the voltage drop due to the activation of the anode and cathode; $\mathrm{V}_{\mathrm{ohm}}$ is a measure of ohmic voltage drop associated with the conduction of the protons through the solid electrolyte and electrons through the internal electronic resistances; $V_{\text {conc }}$ represents the voltage drop resulting from the concentration or mass transportation of the reacting gases. $\mathrm{E}_{\text {Nerst }}$ represent the no-load voltage, while the sum of all the other terms gives the reduction of the useful voltage achievable at the cell terminals, when a certain load current is required. For $\mathrm{n}$ cells connected in series and forming a stack, the voltage $\left(\mathrm{E}_{\text {cell }}\right)$, can be calculated by:

$$
E_{\text {cell }}=n \cdot V_{f c}
$$

In this work a fuel cell unit with an output voltage of $45-24 \mathrm{~V}$ is assumed and the polarization curve is shown in Figure.8. And a high efficiency power conversion system is required for better operation. The power conditioning circuits (PCS) for the fuel cell are inverters and $\mathrm{dc} / \mathrm{dc}$ converters. In almost every application, ac power is required demanding the utilization of an inverter in the power conditioning system [8]. The literature shows multiple types of inverter designs for fuel cell power conditioning system. Also, if more power is required than what is available from the standard size fuel cell, and then modules need to be aggregated. There is more than one approach to aggregate numerous fuel cell modules for high voltage applications. One such approach is the multilevel architecture [11]. In this paper, a hybrid cascaded H-bridge multilevel inverter is proposed for the fuel cell power conditioning system as it not only requires a single dc source in each phase leg and it is highly reliable and efficient.

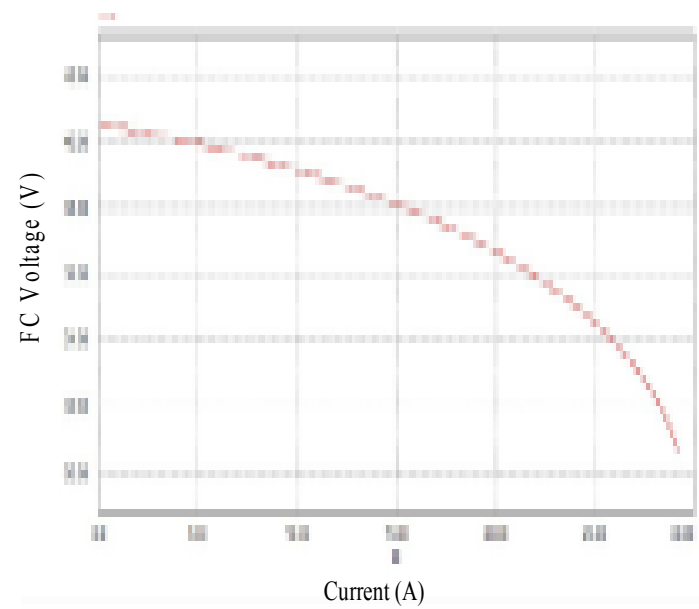




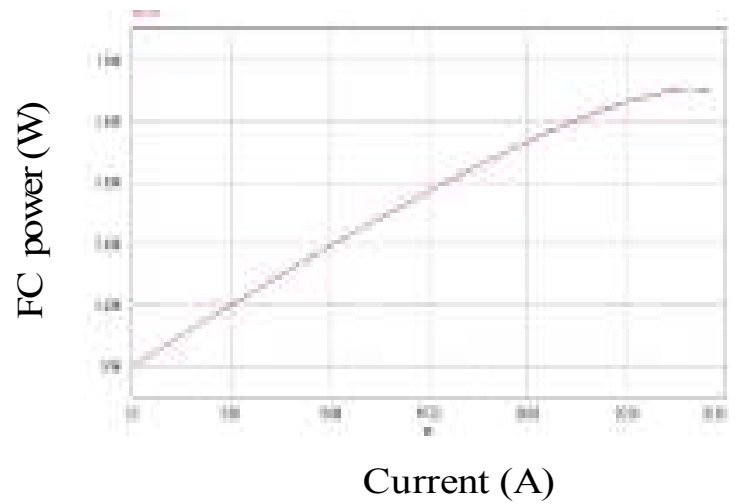

Figure.8 Simulated Polarization curve of PEMFC

\section{SIMULATION RESULTS}

The simulation results for the variable frequency ISPWM based hybrid multilevel inverter for PCS is shown in Figure.9 $\& 10$.

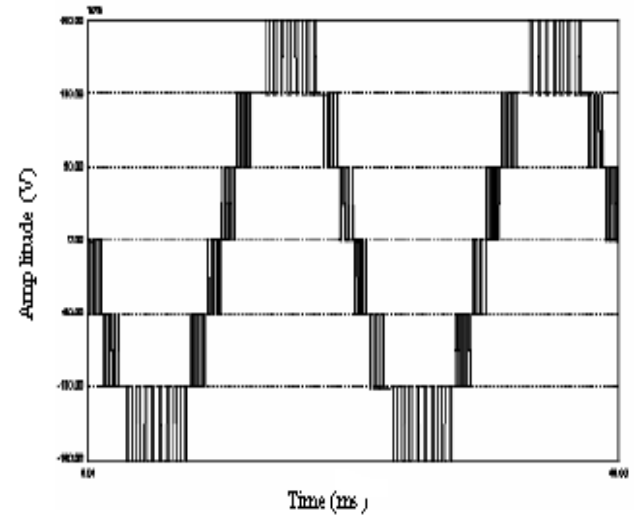

Figure.9 Simulated Phase Voltage Waveforms for the proposed VFISPWM



Figure.10 Output Phase Voltage Spectrum for the proposed VFISPWM

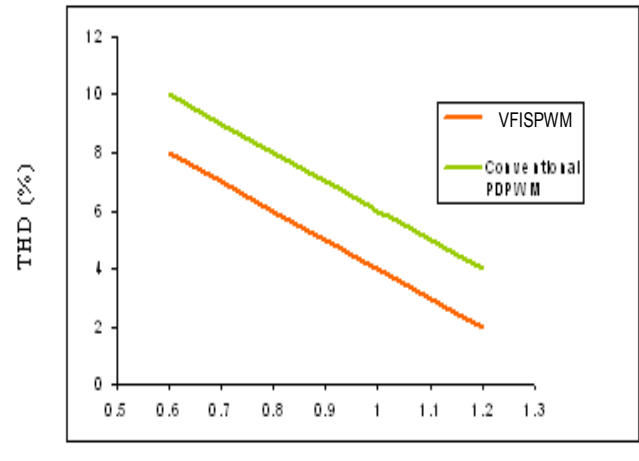

Modulation index

Figure.11 Variation of THD with modulation index for conventional PDPWM and VFISPWM

Figure.11. presents Total Harmonic Distortion (THD) vs. $\mathrm{m}_{\mathrm{a}}$ graph. These results show that the VFISPWM method gives harmonic reduction for individual harmonic. The performance parameters considered for evaluating the proposed modulation strategy are: spectral quality of the output voltage, THD, first-order attenuation of harmonics $\left(\mathrm{DF}_{1}\right)$, second-order attenuation of harmonics $\left(\mathrm{DF}_{2}\right)$ and switching loss [5,9] which is shown in Table 4.

Table 4. Performance Parameters of the Conventional PDPWM and VFISPWM

\begin{tabular}{|l|c|c|}
\hline Parameters & $\begin{array}{l}\text { Conventional } \\
\text { ISPWM }\end{array}$ & $\begin{array}{l}\text { Proposed } \\
\text { VFISPWM }\end{array}$ \\
\hline $\begin{array}{l}\text { THD (\%) } \\
\text { Total Harmonic } \\
\text { Distortion }\end{array}$ & 7.98 & $\mathbf{5 . 4 2}$ \\
\hline $\mathrm{DF}_{1}$ & 0.2 & $\mathbf{0 . 1 5}$ \\
\hline \multicolumn{1}{|c|}{$\mathrm{DF}_{2}$} & 0.12 & $\mathbf{0 . 0 6}$ \\
\hline $\begin{array}{l}\text { Switching } \\
\text { Loss(mJ /Cycle) }\end{array}$ & $6.38 \mathrm{~mJ}$ & $\begin{array}{c}\mathbf{2 . 0 6 m J} \\
\text { Calculated } \\
\text { New } \\
\text { Frequencies - } \\
1596 \mathrm{~Hz}, \\
3443 \mathrm{~Hz} \text { and } \\
3950 \mathrm{~Hz})\end{array}$ \\
\hline
\end{tabular}

The main advantage of the proposed technique is that the number of switching per cycle is same for all the levels. For balancing the switching actions, the choice of the carrier frequency is very important $[10,12]$. Hence, the VFISPWM scheme is more favourable than the conventional PDPWM technique for use in hybrid multilevel inverter for fuel cell power conditioning unit .

\section{EXPERIMENTAL RESULTS}

To experimentally validate the proposed hybrid cascaded $\mathrm{H}-$ bridge multilevel inverter for the PCS, a prototype 7- level inverter has been built using IRF450 MOSFETS as the switching devices. Only one dc source (fuel cell) was used for the hybrid cascaded MLI and the other source being capacitor $(10 \mathrm{mF})$ to generate seven levels. The gating signals for the 
switches ( Figure.1) are generated using FPGA processor as shown in Figures 12 and 13. The experimental waveform for the proposed MLI using conventional PDPWM and VFISPWM for fuel cell is shown in Figures 14 and 15. The experimental THD value of hybrid MLI employing VFISPWM is shown in Figure.16. (IEEE acceptable limit is $5 \%)$



Figure 12 Gating pattern for Bridge $\mathrm{H}_{1}$

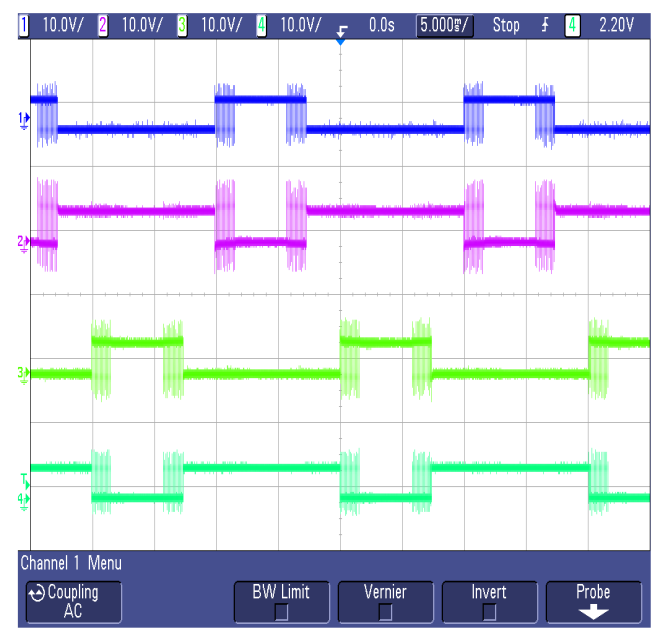

Figure 13 Gating pattern for bridge $\mathrm{H}_{2}$

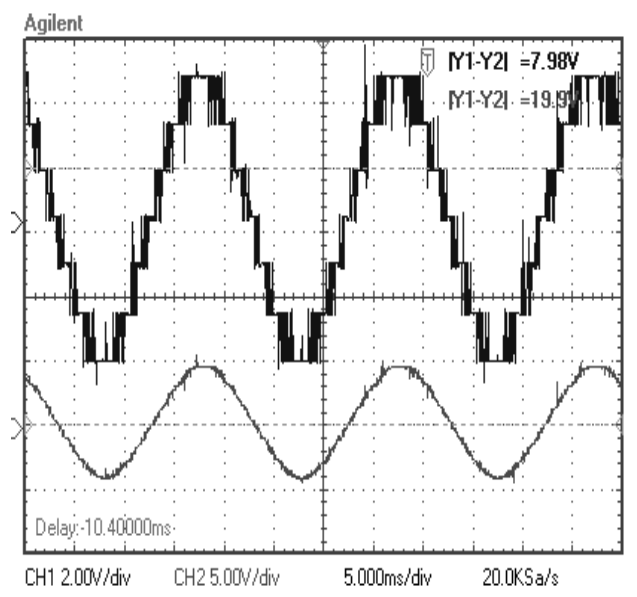

Figure.14 Experimental Equal 7-level Output Voltage and Current Waveform for the Hybrid Inverter (Conventional PWM)
Volume 9-No.1, November 2010

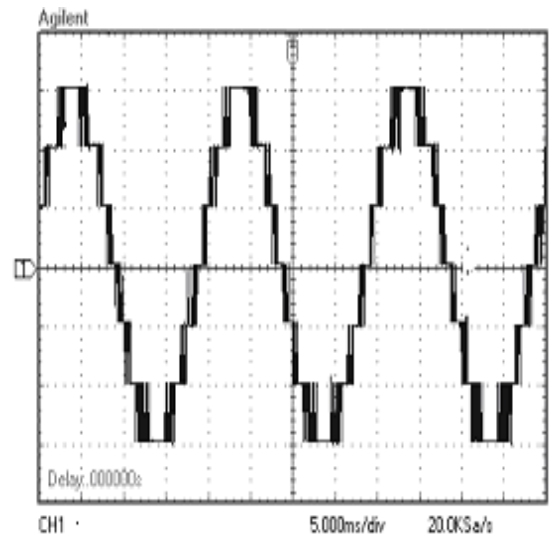

Figure.15 Line - neutral voltage for Hybrid MLI with VFISPWM. $\left(m_{\mathrm{f} 3}=32, \mathrm{~m}_{\mathrm{f} 2}=69, \mathrm{~m}_{\mathrm{f} 1}=79\right)$

E्व V Harmonics 2010-04-05, 12:24

$49.5 \mathrm{~Hz}[1]$

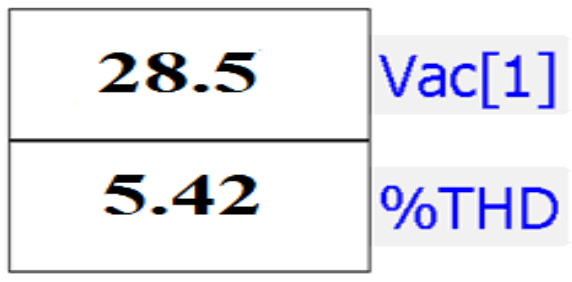

Figure 16 Experimental THD for VFISPWM

\section{CONCLUSION}

In this paper, a novel modulation technique has been investigated for hybrid MLI suited for fuel cell applications. A single dc power source and two H-bridges for each phase have been used as a good tradeoff between performance and cost The performance parameters of HCMLI are studied by employing the proposed VFISPWM method for linear loads. From the results, it has been concluded that VFISPWM gives a lower switching losses and THD for a chosen modulation index compared to the conventional PDPWM.This power conditioning system is suitable for high power fuel cell modules and variable frequency ISPWM gives a THD of $5.42 \%$ which is verified experimentally.

\section{REFERENCES}

[1] D. Zhong , L.M.Tolbert, J,NChiasson, B.Ozpineci, Li Hui,and A.Q.Huang, "Hybrid cascaded H-bridges multilevel motor drive control for electric vehicles", in Proc. $37^{\text {th }}$ IEEE Power Electronics Specialists Conference, PESC'06, June 2006,pp.1- 6 .

[2] R.Seyezhai and B.L.Mathur,"Harmonic evaluation of multicarrier PWM techniques for cascaded multilevel inverter", in Proc. 2nd International Conference on Electrical Engineering and its Applications, Algeria, ICEEA 2008, 2021 May 2008, pp. 3 - 8 .

[3] M.G.H.Aghdam, S.H.Fathi, G.B.Gharehpetian, "Analysis of multicarrier PWM methods for asymmetric multilevel inverter" in Proc. 3rd IEEE Conference on Industrial Electronics and Applications, ICIEA'08, June 2008, pp.2057 2062. 
[4] M.Calais, L. J. Borle and V.G. Agelidis, "Analysis of Multicarrier PWM Methods for a Single-phase Five Level Inverter", in Proc. 32nd IEEE Power Electronics Specialists Conference,PESC'01,July 2001,pp 1351-1356.

[5] Radan, A.H.Shahirinia, M.Falahi, "Evaluation of CarrierBased PWM Methods for Multi-level Inverters" in Proc. IEEE International Symposium on Industrial Electronics,ISIE07, June 2007,pp.389-394.

[6] Z.D.Far, A.Radan, M.D.Far, "Introduction and Evaluation of novel multi-level carrier based PWM strategies using a generalized algorithm", in Proc. European Conference on Power Electronics and Applications, EPE'07, September 2007, pp.1 -10.

[7] S.Jeevananthan, R.Nandhakumar, P.Dananjayan."Inverted Sine Carrier for Fundamental Fortification in PWM Inverters and FPGA Based Implementations".Serbian Journal of Electrical Engineering, Vol. 4, No. 2, November 2007, 171187.

[8] L. M. Tolbert, F. Z. Pcng, "Multilevel converter as an utility interface for renewable energy systems," IEEE Power Engineering Society Summer Meeting, Washington, July 2000, vol.2, pp. 1271-1274.

[9] McGrath B.P, Holmes D.G. "Multicarrier PWM strategies for Multilevel Inverters", IEEE Transactions on Industrial Electronics, Vol.49, Issue 4, Aug. 2002, Pages: 858 - 867.

[10] B.P. McGrath and D.G. Holmes, "A Comparison of Multicarrier PWM strategies for Cascaded and Neutral point Clamped Multilevel Inverters", in Proc. IEEE PESC'00, 2000, pp. 674-679.
[11] B. Ozpineci, L. M. Tolbert, Zhong Du, "Optimum fuel cell utilization with multilevel inverters," in Proc. IEEE 35th Power Electronics Specialist Conference, PESC'04, June 2004, vol.6, pp. $4798-4802$.

[12] H.Keivani, M.R.Askari, F.Kavahnia, Aghdam, A. Mohammadi, "Novel multicarrier PWM method for a threephase cascaded H-bridge multilevel inverter", in Proc. 41st International Universities Power Engineering Conference, UPEC 2006, 6- 8 September 2006, vol .2, pp- 593 - 597.

\section{BIOGRAPHY}

R.Seyezhai obtained her B.E. (Electronics \& Communication Engineering) from Noorul Islam College of Engineering, Nagercoil in 1996 and her M.E in Power Electronics \& Drives from Shanmugha College of Engineering, Thanjavur in 1998. She has been working in the teaching field for about 12 Years. She has published 50 papers in the area of Power Electronics $\&$ Drives. Her areas of interest include SiC Power Devices \& Multilevel Inverters.

Dr.B.L.Mathur obtained his B.E. (Electrical Engineering) from University of Rajasthan, in 1962 and his M.Tech in Power Systems from IIT, Bombay in 1964.He completed his Ph.D. in 1979 from IISc, Bangalore. His Ph.D. thesis was adjudged as the best for application to industries in the year 1979 and won gold medal. He has been working in the teaching field for about 44 Years. He takes immense interest in designing Electronic circuits. He has published 40 papers in National and International journals and 85 in National and International conferences. His areas of interest include Power Devices, Power Converters, Computer Architecture and FACTS 